\title{
Change Management of Islamic Boarding Schools (Phenomenology Study at the Sumatra Thawalib Parabek Islamic Boarding School Bukitinggi)
}

\author{
Muhammad Fazis, Bedjo Sujanto, Makruf Akbar \\ \{fazismuhammad@yahoo.co.id ${ }^{1}$, bejosujanto@unj.ac.id ${ }^{2}$ \} \\ Universitas Negeri Jakarta, Indonesia ${ }^{123}$
}

\begin{abstract}
This study focuses on the change management of the Thawalib Parabek Islamic boarding school from the elements of educators and education staff. This research was carried out using a qualitative approach with phenomenological methods. Data was collected by interviews, observation, study documentation, and field notes. Data analysis is conducted by reducing, coding, categories and setting themes. The data validity test was done through triangulation. The results of the study show that the Sumatra Islamic Boarding School Thawalib Parabek has engaged in some management changes in educators and education personnel including planning, recruitment, selection, orientation, placement and utilization, guidance and development, compensation, assessment of work implementation, and dismissal.
\end{abstract}

Keyword: Management, Islamic Boarding School, Thawalib Parabek

\section{Introduction}

The Sumatra Islamic Boarding School Thawalib Parabek made changes by modifying its organizational elements to attain better existence, development, and effectiveness, Winardi (2005: 80). Making adequate changes will produce a shift in the present conditions resulting in the desired ones, Pott and L. Marsh as quoted by Wibowo (2012). Changes can be caused by internal factors, such as improvements in educator management, staff education, and organizational culture. External factors such as competition between educational institutions, the demands of the community for quality education, socio-cultural, economic, demographic, political and technological developments.

The targets of change management of the Sumatra Islamic Boarding School of Thawalib Parabek are the educators and education staff, Harvey and Brown (1992: 57) and Winardi (2005: 93). Change management of the educators and education personnel includes planning, recruitment, selection, orientation, utilization, guidance and development, compensation, assessment of work implementation, and dismissal. Changes are planned, incremental and fundamental and adaptive. 
The leadership of the Foundation and the lodge is responsible for accelerating change, Robin (2001). Change resistance comes from individuals and organizations. Individual resistance occurs when people do not know the change, do not understand the needs of change and habits in carrying out the tasks. Organizational resistance occurs because madrasa leaders and coordinators are slow to implement changes (structural inertia), Green and Baron in Wibowo (2012). Educators and education staff support change just because it is their responsibility and because they desire better working conditions, Kirkpatrick in Wibowo (2012). Change resistance is overcome by inviting educators and education staff to participate in giving responses and suggestions for the changes to be made, to socialize and provide adequate training for skill enhancement during its implementation, Hussey, Pott and LaMarsh in Wibowo (2012).

\section{Methodology}

This research was carried out at the Sumatara Thawalib Parabek Bukitinggi Islamic Boarding School in West Sumatra for nine months using a qualitative approach with phenomenological methods. Data were collected through interviews, observation and documentation studies. The data collation instruments used were a list of interviews, researchers, sound recorders, cameras, the hand came and field notes. The analysis was performed by reducing, coding, categories and setting themes. Testing the validity of data through triangulation.

\section{1 Result and Discussion}

The results showed that the change management regarding educators and educational staff of the Thawalib Parabek Islamic boarding school was performed by planning, recruitment, selection, orientation, placement, coaching, job evaluation, compensation and dismissal of educators and education staff.

\section{1 Planning and education staff}

planning was carried out through job analysis by estimating the work to be done, and the qualifications of personnel needed based on the number of students that must be served administratively and academically at the Foundation's policies in organizational development, Mondy (2008)

\section{2 Recruitment of educators and education staff}

Recruitment of educators and education personnel was achieved by effective advertisements in the electronic and print media such as Bukittingi TV, Padang Ekspres, and Republika daily newspapers to provide information to applicants so that those with the needed attitudes and skills will be gainfully employed, Ivancevic (2013: 12 


\subsection{Selection of educators and education staff}

Administrative selection and non-administrative selection. The administrative selection includes the suitability of applications with formations, qualifications, documents and cumulative index. The non-administrative or academic selection has to do with applicants' knowledge (cognitive test), teaching skills tests, reading books, language skills and learning the Qur'an (motoric cognitive test). Personality tests and interests were conducted through interviews to discover the personality of applicants, some of which includes questions like have you ever been dating, what kind of clothing models are often used, have you ever smoked. Commitment test was also done to find out the promise of service for Islamic boarding schools, Hanggareani (2012).

\subsection{Orientation of educators and education staff}

The orientation was performed to help educators and education staff understand the history, physical, social, regulatory, development of the Sumatra Islamic Boarding School Thawalib Parabek as well as the rights and obligations, the task of educators and education staff as employees of the Syaikh Ibrahim Musa Parabek Foundation Raymond A. Noe (2011).

\subsection{Placement and utilization of educators and education staff}

The placement of educators and education personnel was by educational qualifications. Educators who have S1 diplomas in mathematics teach mathematics, education staff with D3 in informatics management diplomas were placed in information technology laboratories, Sastrohadiwiryo in Yunarsih (2009: 17). Educators and education staff were utilized as coaches of students in the dormitory and coordinators of discipline and worship.

\subsection{Coaching and development of educators and education staff}

development of educators and education staff was carried out through training activities, Teacher Working Groups and Teacher's Consultative Groups, with the aim of increasing their knowledge and skills to enable them perform their tasks effectively, Noe (2011) and Hanggareani (2012)

\subsection{Performance appraisal of educators and education staff}

The educator's performance assessment was performed on four domains - first, effective which includes discipline, loyalty, responsibility and willingness to sacrifice. Lesson plans and observations consist of plans for learning programs and their implementation in class. Third, creativity which has to do with the efforts of the teacher to obtain teaching materials, learning resources, and teaching aids. Four, academics covers the achievement of teaching completeness criteria. Assessment of the performance of education personnel consists of effective, creativity, implementation of tasks (psychomotor) and work results. The affective assessment had a total weight of $40 \%$, creativity $25 \%$, psychomotor (lesson plan / administrative task) $20 \%$, and academic / work results $15 \%$. The data collected from the assessment in the form of percentages 
were converted to letters A, B, C, D and E. Job evaluation provides an overview of the successful implementation of the work of educators and education personnel, Nawawi (2011).

\subsection{Compensation of educators and education staff}

Direct compensation received by educators and education personnel were basic salary, position allowance, honorarium, and reward. Indirect financial compensation in the form of labor social security, health insurance, old age benefits, housing savings, and hajj departure was also received by the educators and education personnel. Other forms of rewards include laptop, watches, books, and money. The salary increase was about $5 \%$ which was given once in 4 years, and the returns increased by $20 \%$ every year if the implementation of work is worth A. B $15 \%$, C $10 \%$, D 5\%, and warning letters and E do not get a salary increase. Salary, honorarium, and rewards received were awarded to educators and education staff for performing their duties. Nawawi (2011: 315).

\subsection{Dismissal of educators and education personnel}

Dismissal of educators and education personnel was a result of undisciplined behavior, such as regular lateness. General misconduct such as females following their husband on duty elsewhere, Entering retirement age (60 years). Dismissal of educators and education personnel were based on the regulations of the employees of the Parabek Syaikh Ibrahim Musa Foundation. The termination process in regards to behavioral violation begins with guidance; if changed is not observed from the first and second, termination warning letters are given. Dismissal will be given by the Parabek Syaikh Ibrahim Musa Foundation to the educators and education staff. Yuniarsih (2009: 8).

\section{Conclusion}

The data obtained from this study shows that the change management in educators and education staff is performed through (1) Planning which includes study groups, the number of subjects, the delivery hours of each subject and the mandatory teaching hours of each teacher. (2) Recruitment which begins with the announcement of formation in the local and national mass media, followed by the registration of prospective educators and education staff. (3) Administrative, academic, personality and commitment. (4) The historical orientation of the Thawalib Parabek Islamic boarding school, vision, mission, goals, strategies, core values as well as quality assurance, communication ethics and the rules of the employees of the Shaykh Ibrahim Musa Parabek foundation and basic tasks. (5) The placement/utilization of educators and education personnel was done by giving assignments by educational background. (6) Giving compensation or incentives, rewards and salary increase with a general system increase and rate increase. (7) Guidance and development are carried out through competency improvement training, seminars, workshops, further education, teacher working groups and subject matter teacher meetings. Development is done by promotion. (8) Assessment of effective work, creativity, psychomotor and work results. (9) Dismissal is issued when staff 
enters retirement age and also at their request. Dismissal is also issued when a serious offense is committed.

\section{References}

[1] Hanggaraeni.: Dewi, Jakarta Manajemen Sumber Daya Manusia, Jakarta, Fakultas Ekonomi Universitas Indonesia, (2012)

[2] Harvey, Donal F dan Donal F. Brow.: An Experiental Approach to Organizational Development. New Jersey: Printice Hall, (1992)

[3] Ivancevich, Jhon M.: Human Resource Management, New York, Mc. Graw-Hill International Edition, (2013)

[4] Mondy, R. Wayne.: Manajemen Sumber Daya Manusia, Jakarta: Erlangga, (2008)

[5] Nawawi, Hadari. Manajemen Sumber Daya Manusia, Yogyakarta, Gadjah Mada University Press, (2011).

[6] Noe,et al.: Raymon A Fundamentals of Human Resource Management, Mc. Graw-Hill, New York, (2011)

[7] Robbins, Stephen P dan Timothy A.: Judge. Organizational Behavior. London: Pearson Education, Inc, (2009).

[8] Wibowo.: Manajemen Perubahan. Jakarta: Rajawali Pers, 2012.Winardi, J. Manajemen Perubahan. Jakarta: Kencana Prenada Media Group, (2010). 